\title{
Evaluation of educational environment of Nursing Undergraduates
}

\author{
Hettiarachchi Manjula ${ }^{1}$, Chandana NGASS ${ }^{2}$ \\ ${ }^{\prime}$ Nuclear Medicine Unit, ${ }^{2}$ Allied Health Science Degree Programme,Faculty of Medicine, University of Ruhuna, \\ Galle, Sri Lanka
}

Correspondence: Dr.MajulaHettiarachchi; (manjula.hettiarachchi@gmail.com)

\begin{abstract}
Objective: To assess the undergraduate nursing educational environment in University of Ruhuna.

Methods: Prospective study using the already validated Dundee Ready Education Environment (DREEM) questionnaire (50 items scored on a 0 - 4 Likert scale) among nursing students $(n=55)$ enrolled to the degree programme in the academic year 2010/2011.

Results: The mean total score was 109 (out of a maximum of 200) indicating relative satisfaction with the perceived environment and 'the students' perceptions of learning - teaching was viewed negatively; perceptions of teachers - the school is moving in the right direction; academic self perceptions - there are many negative aspects; perceptions of the atmosphere - there are many issues that require change; and 'students' social-self perceptions - the school is not too bad. There were no individual areas of excellence (item scored $>3.5$ ).
\end{abstract}

Conclusions: This tool identified areas that need improvements across all five domains of the educational environment.

Key words: DREEM questionnaire, Education environment, Nursing students

\section{Introduction}

Educational environment is the environment experienced or perceived by the students as well as by the teachers (1). In the modern medical education, more emphasize is given for assessing the educational environment on which the student learn and to know how it had affected the learning in those particular student populations. It is evident from research that, the educational environment plays a significant role in relation to a student's behavior, academic development as well as their feeling of well-being while undergoing the training programme (2). Roff et al. (3) developed the Dundee Ready Education Environment Measure (DREEM) and validated it in a wide range of countries (4-7). It has fulfilled a long-felt need for a test instrument specifically meant to evaluate health professions education institutions (7).
It can produce global reading and diagnostic analyses of undergraduate educational environments in medical schools and other health professions institutes.

The aim of this research was to examine students' perceptions of the educational environment created by a new nursing curriculum in order to identify areas which need modifications. The findings of the study will be used to monitor the programme's initial implementation and also as longitudinal evidence to support the programme's first major review in coming years. Therefore, it is beneficial to assess how the nursing students perceive the new educational environment. 


\section{Methods}

\section{Instrument}

The DREEM contains 50 statements relating to a range of topics directly relevant to the educational climate. Nine of the 50 items are negative statements. Each item should be scored 0 - 4 with 4 = Strongly agree, 3 = Agree, $2=$ Unsure, $1=$ Disagree and $0=$ Strongly disagree with a maximum score 200 . Negative items should be scored in reverse order so that the higher a score the more positive the perception for all items. The 50 items assess five domains, namely students' perception of learning (12 items), students' perception of teachers (11 items), students' academic self perception (8 items), perception of atmosphere (12 items), and the student's social self perception ( 7 items).

The survey of the educational environment was conducted in Allied Health science programme of the Faculty of Medicine, University of Ruhuna, during the month of March, 2011 after obtaining the approval from the Ethical Review Committee of the Faculty of Medicine. The DREEM was administered to all students studying in the third and second years (first and second batch of students respectively). Students were given 60 minutes free time during a lecture class to respond to the inventory. All students present in the class on the day of the survey were asked to respond to the items of the inventory on a four point Likert-type scale.

Mean value for the total perception and five sub areas as well as scale scores were compared between batches at 5\% level of significance, applying the Students' t-test using SPSS 14.0 version.

\section{Results}

There were 62 students following the B.Sc. nursing programme of the Faculty of Medicine University of Ruhuna. Of them, 55 participated in this survey (34 females). Others $(n=7)$ did not turn up for our request. The study group included 29 students in the second year (second batch) and 26 students in the third year (first batch). Nursing students' mean (SD) age was $23.8(0.5)$ years among first batch of students and 23.0 (0.9) among second batch of students, respectively.
Nursing students overall mean DREEM score was 109 out of 200 and it indicates that it is a more positive environment (Table 1). The other domains of interest (i.e., perception of learning; perception of teachers; academic self perception and social self perception) were on more satisfactory end of the scale whereas they felt that more attention was needed on atmosphere. The mean score on perception of atmosphere was 22 out of 48 (Table 1). This mark was in the range of 13-24 out of 48 and could be interpreted as 'there are many issues which need changing'. There was no significant difference for the overall perception to the educational environment according to the age $(p=0.31)$ and gender $(p=0.14)$ (data not shown).

The senior batch of students (i.e., $3^{\text {rd }}$ year) felt social environment as "not a nice place" (mean score of 13.96 (2.07) whereas the junior students (second batch) felt it "not too bad" (mean score of 15.66 (2.22); $\mathrm{p}=0.005)$. Table $2-6$ summarizes the maximum mean score for the item analysis of each domain.

\section{Discussion}

Following the establishment of the Nurses Training Schools (NTS) 72 years ago (i.e., 1939) in Sri Lanka, the main focus was training adequate numbers of nurses to meet the shortage of nurses in the country. Throughout this period little attention, if any, has been paid to understand how students feel about and participate in the diploma course during three years of their study. The Allied Health Sciences Degree Programme is a new initiative of the Faculty of Medicine, University of Ruhuna, and it was implemented in 2007. The first intake was recruited in 2008 with previous year (i.e., 2007/2008) Advanced Level (A/L) students who sat for their General Certificate of Examination (GCE). Two new degree programs were established namely, Nursing and Medical Laboratory Sciences. Some other universities in Sri Lanka are also following the same as per University Grants Commission (UGC) directive to expand the scope of the universities as well as to improve the higher educational opportunities in the country.

The Dundee Ready Education Environment Measure (DREEM) is used to assess the educational climate, particularly in the realm of health and 
medicine (3). This tool can be used to highlight the strengths and weaknesses of an educational institution, compare the performance and effectiveness of different medical schools, and make comparisons among students in different years of study and differences between the genders $(5,8)$. In addition, this instrument is used to help modify the curriculum, comparing past and present curricula and evaluating the efficacy of a university program $(6,9)$. It can help medical and health schools to recognize their educational priorities and introduce more effective measures as a result. Furthermore, it enables institutions to compare their performances and productivities with their peers, which can be educationally insightful (10).
Till (11) utilized DREEM to make a comparison between the actual educational climate as perceived and experienced by students and the ideal one; the findings can be used to implement improvements in educational settings.

The objective of this study was to obtain students perception to the academic environment during their 4 year degree program. When look at the overall results, second batch student's perception was high in areas of learning, teachers and academic self perception, atmosphere social self perception in comparison to the first batch students. The low scores of the first batch nursing students might have been due to the fact that they had more hardships during the initial period of the school due to lack of facilities, uncertainties of clinical training etc.

Table 1: Nursing students' perception to the education environment and its' interpretation ${ }^{1}$

\begin{tabular}{|c|c|c|c|c|}
\hline \multirow[t]{2}{*}{ Areas of perception $\&$ reference range } & \multicolumn{3}{|c|}{ Perception Mean (SD) } & \multirow[t]{2}{*}{ Interpretation } \\
\hline & $\begin{array}{c}\text { Second } \\
\text { Batch }\end{array}$ & $\begin{array}{c}\text { First } \\
\text { Batch }\end{array}$ & Over all & \\
\hline $\begin{array}{l}\text { 1. Perception of learning } \\
0-12 \text { Very Poor; } 13-24 \text { Teaching is viewed } \\
\text { negatively; } 25-36 \text { A more positive perception; } \\
37-48 \text { Teaching highly thought of }\end{array}$ & $\begin{array}{l}27.97 \\
(4.27)\end{array}$ & $\begin{array}{l}26.23 \\
(4.44)\end{array}$ & $\begin{array}{l}27.14 \\
(4.39)\end{array}$ & $\begin{array}{l}\text { More positive } \\
\text { perception }\end{array}$ \\
\hline $\begin{array}{l}\text { 2. Perception of Teachers } \\
0 \text {-11 Abysmal; } 12-22 \text { In need of some } \\
\text { retraining; 23-33 Moving in the right } \\
\text { direction; } 33-44 \text { Model course organizers }\end{array}$ & $\begin{array}{l}26.97 \\
(4.40)\end{array}$ & $\begin{array}{l}25.96 \\
(3.67)\end{array}$ & $\begin{array}{l}26.49 \\
(3.86)\end{array}$ & $\begin{array}{l}\text { Teaching is } \\
\text { moving in the } \\
\text { right direction }\end{array}$ \\
\hline $\begin{array}{l}\text { 3. Academic self perception } \\
0 \text { - } 8 \text { Feelings of total failure; } 9-16 \text { Many } \\
\text { negative aspects; } 17-24 \text { Feeling more on } \\
\text { the positive side; } 25-32 \text { Confident }\end{array}$ & $\begin{array}{l}17.93 \\
(3.99)\end{array}$ & $\begin{array}{l}17.92 \\
(2.46)\end{array}$ & $\begin{array}{l}17.92 \\
(3.32)\end{array}$ & $\begin{array}{l}\text { More on the } \\
\text { positive side }\end{array}$ \\
\hline $\begin{array}{l}\text { 4. Perception of atmosphere } \\
\text { 0-12 A terrible environment; 13-24 There } \\
\text { are many issues which need changing; 25-36 } \\
\text { A more positive attitude; 37-48 A good } \\
\text { feeling overall }\end{array}$ & $\begin{array}{l}22.52 \\
(5.55)\end{array}$ & $\begin{array}{l}22.04 \\
(5.53)\end{array}$ & $\begin{array}{l}22.29 \\
(5.49)\end{array}$ & $\begin{array}{l}\text { There are many } \\
\text { issues which } \\
\text { need changing }\end{array}$ \\
\hline $\begin{array}{l}\text { 5. Social self perception } \\
\text { 0-7 Miserable; 8-14 Not a nice place; } 15-21 \\
\text { Not too bad; 22-28 Very good socially }\end{array}$ & $\begin{array}{l}15.66 \\
(2.22)\end{array}$ & $\begin{array}{l}13.96 \\
(2.07)\end{array}$ & $\begin{array}{l}14.85 \\
(2.28)\end{array}$ & $\begin{array}{l}\text { Social life is } \\
\text { not too bad. }\end{array}$ \\
\hline $\begin{array}{l}\text { 6. Overall perception } \\
\text { 0-50 Very Poor; 51-100 Plenty of Problems; } \\
\text { 101-150 More Positive than Negative; } \\
\text { 151-200 Excellent }\end{array}$ & $\begin{array}{l}111.0 \\
(15.8)\end{array}$ & $\begin{array}{l}106.1(15 \\
.1)\end{array}$ & $\begin{array}{l}108.71 \\
(15.54)\end{array}$ & $\begin{array}{l}\text { More positive } \\
\text { environment } \\
\text { than negative }\end{array}$ \\
\hline
\end{tabular}

${ }^{1}$ Results presented as mean (SD); reference ranges for the mean scores were from 
Of the 50 items on the DREEM inventory, 31 items had mean scores between 2.00 and 3.00. These items are aspects of the educational environment that could be enhanced (12). A total of 16 items scored below 2.00. These could be identified as problem areas in nursing degree programme educational environment that require further improvements. Only 3 items scored more than 3.0, which indicate that these areas are the satisfactory areas in their present educational environment. Furthermore, no item received a mean score $\geq 3.5$. A mean score $\geq 3.5$ indicates particularly positively-rated items. The high scores in academic self perception among nursing students can be attributed to the high perception about empathy in their profession and most of the learning was relevant to their profession. However, these students were yet to prepare for their profession as they were in the early phase of the clinical appointments.

In a report from a Thai nursing school, $14.8 \%$ of students rated their institution below $50 \%$ and generally the scores decreased from the first year to the second year nursing course and increased from the second year to the third and fourth year nursing course in all 5 scales (4). This decrease may be because first year students are not experienced enough to give a valid report of the educational process.
This may be supported by the observation of till (11) that first year students in particular sometimes gave mixed messages which may have contributed to lower the scores.

A few limitations affected this study's outcomes. First, the sampling frame was restricted to one nursing school. Therefore, the generalizability of the findings is expected to be limited and the results are not representative of all tertiary nursing students in Sri Lanka. Furthermore, studies should be carried out in other institutions to determine student opinions using the revised DREEM questionnaire. Second, respondent honesty is also a potential source of error in self-report surveys (13), which are based solely on the subjective views of the participants themselves. This may possibly cause a response bias from each respondent (14). The validity and accuracy of students' perceptions of their learning and the learning environment has been questioned (15).

The conclusions include the need for the creation of a supportive, creative and conducive environment, focusing on unsatisfactory elements to bring desirable changes in the educational environment to meet the challenges of health care profession.

Table 2: Mean values for items of learning perception among nursing students ${ }^{1}$

\begin{tabular}{lcc}
\hline \multicolumn{1}{c}{ Item } & \multicolumn{2}{c}{ Perception } \\
\cline { 2 - 3 } & Second Batch & First Batch \\
\hline I am encouraged to participate in class & 2.86 & 2.61 \\
The teaching is often stimulating* & 2.51 & 2.03 \\
The teaching is student centered & 2.27 & 2.11 \\
The teaching helps to develop my competence & 2.72 & 2.61 \\
The teaching is well focused* & 2.37 & 1.88 \\
The teaching helps to develop my confidence & 2.62 & 2.50 \\
The teaching time is put to good use & 2.34 & 2.11 \\
The teaching over emphasizes factual learning & 1.72 & 1.80 \\
I am clear about the learning objectives of the course & 1.79 & 1.53 \\
The teaching encourages me to be an active learner & 2.03 & 2.30 \\
Long term learning is emphasized over short term learning & 2.48 & 2.42 \\
The teaching is too teacher-centered & 2.20 & 2.26 \\
\hline
\end{tabular}

${ }^{1}$ There were 29 students in $2^{\text {nd }}$ year and 26 students in $3^{\text {rd }}$ year; the items in italics were negative questions.

*There were significant differences between two batches ( $\mathrm{p}=0.05$; independent sample $\mathrm{t}$-test). 
Table 3: Mean values for perception of teachers among nursing students ${ }^{1}$

\begin{tabular}{lcc}
\hline \multicolumn{1}{c}{ Item } & \multicolumn{2}{c}{ Perception } \\
\cline { 2 - 3 } & Second Batch & First Batch \\
\hline The Teachers are knowledgeable* & 3.28 & 2.58 \\
The Teachers are patient with patients & 2.38 & 2.62 \\
The Teachers ridicule the students & 2.34 & 2.46 \\
The Teachers are authoritarian & 1.76 & 1.85 \\
The Teachers have good communication skills with patients & 2.38 & 2.19 \\
The Teachers are good at providing feedback to students & 2.45 & 2.31 \\
The Teachers provide constructive criticism here & 1.79 & 1.96 \\
The Teachers give clear examples & 2.79 & 2.69 \\
The Teachers get angry in class & 2.62 & 2.50 \\
The Teachers are well prepared for their classes* & 2.69 & 2.12 \\
The students irritate the teachers & 2.48 & 2.69 \\
\hline
\end{tabular}

${ }^{1}$ There were 29 students in $2^{\text {nd }}$ year and 26 students in $3^{\text {rd }}$ year; the items in italics were negative questions

*There were significant differences between two batches ( $\mathrm{p}=0.05$; independent sample $\mathrm{t}$-test)

Table 4: Mean values for academic self perception among nursing students ${ }^{1}$

\begin{tabular}{lccc}
\hline \multicolumn{1}{c}{ Item } & \multicolumn{2}{c}{ Perception } \\
\cline { 2 - 3 } & $\begin{array}{c}\text { Second } \\
\text { batch }\end{array}$ & $\begin{array}{c}\text { First } \\
\text { batch }\end{array}$ \\
\hline Learning strategies which worked for me before continue to work for me now & 2.17 & 2.19 \\
I am confident about passing this year & 2.28 & 2.15 \\
I feel I am being well prepared for my profession & 1.93 & 2.04 \\
Last year's work has been a good preparation for this year's work & 2.28 & 2.12 \\
I am able to memorize all I need & 1.72 & 1.85 \\
I have learned a lot about empathy in my profession & 3.00 & 2.69 \\
My problem solving skills are being well developed here & 1.97 & 2.23 \\
Much of what I have to learn seems relevant to a career in healthcare & 2.59 & 2.65 \\
\hline
\end{tabular}

${ }^{1}$ There were 29 students in $2^{\text {nd }}$ year and 26 students in $3^{\text {rd }}$ year; the items in italics were negative questions 
Table 5: Mean values for perception on academic atmosphere among nursing students ${ }^{1}$

\begin{tabular}{lcc}
\hline \multicolumn{1}{c}{ Item } & \multicolumn{2}{c}{ Perception } \\
\cline { 2 - 3 } & Second Batch & First Batch \\
\hline The atmosphere is relaxed during the ward teaching & 0.83 & 1.15 \\
The school is well timetabled & 0.79 & 0.77 \\
Cheating is a problem in this school & 1.97 & 1.73 \\
The atmosphere is relaxed during lectures & 2.17 & 2.04 \\
There are opportunities for me to develop interpersonal skills & 2.03 & 1.85 \\
I feel comfortable in class socially & 2.24 & 2.27 \\
The atmosphere is relaxed during seminars/tutorials & 2.34 & 1.92 \\
I find the experience disappointing & 1.52 & 1.62 \\
I am able to concentrate well & 2.45 & 2.46 \\
The enjoyment outweighs the stress of the course & 1.69 & 1.85 \\
The atmosphere motivates me as a learner & 1.97 & 1.96 \\
I feel able to ask the questions I want & 2.52 & 2.42 \\
\hline
\end{tabular}

${ }^{1}$ There were 29 students in $2^{\text {nd }}$ year and 26 students in $3^{\text {rd }}$ year; the items in italics were negative questions

Table 6: Mean values for social self perception among nursing students ${ }^{1}$

\begin{tabular}{lcc}
\hline \multicolumn{1}{c}{ Item } & \multicolumn{2}{c}{ Perception } \\
\cline { 2 - 3 } & Second Batch & First Batch \\
\hline There is a good support system for students who get stressed & 1.38 & 1.19 \\
I am too tired to enjoy the course & 1.55 & 1.35 \\
I am rarely bored on this course & 1.93 & 1.58 \\
I have good friends in this course & 3.03 & 3.00 \\
My social life is good & 2.93 & 2.81 \\
I seldom feel lonely & 2.28 & 1.96 \\
My accommodation is pleasant & 2.55 & 2.08 \\
\hline
\end{tabular}

${ }^{1}$ There were 29 students in $2^{\text {nd }}$ year and 26 students in $3^{\text {rd }}$ year

\section{Acknowledgements}

All nursing undergraduates who participated in this study.

\section{References}

1. Jamaiah, I. Review of research in learning environment. Journal of Medical Education 2008; 11(1);7-11.

2. Genn, JM (2001). Curriculum, environment, climate quality and change in medical education - a unifying perspective. Medical Teacher 2001; 23(5): 445-54.
3. Roff S, McAleer S, Harden R, Al-Qahtani M, Ahmed AU, Deza H, Groenen G, Primparyon P: Development and validation of the Dundee Ready Education Environment Measure (DREEM). Med Teacher 1997; 19(4): 295-99.

4. Pimparyon P, Caleer SM, Pemba S, Roff S: Educational environment, student approaches to learning and academic achievement in a Thai nursing school. Med Teacher 2000; 22(4): 359-64. 
5. Roff S, McAleer S, Ifere OS, Bhattacharya S. A global diagnostic tool for measuring educational environment: comparing Nigeria and Nepal. Med Teach 2001; 23(4): 378-82.

6. Bassaw B, Roff S, McAleer S, Roopnarinesingh S, De Lisle J, Teelucksingh S, Gopaul S: Students' perspectives on the educational environment, Faculty of Medical Sciences, Trinidad. Med Teacher 2003; 25(5): 522-6.

7. Jiffry MT, McAleer S, Fernando S, Marasinghe RB. Using the DREEM questionnaire to gather baseline information on an evolving medical school in Sri Lanka. Med Teach 2005; 27(4): 348-52.

8. Mayya S, Roff S: Students' perceptions of the educational environment: a comparison of academic achievers and under-achievers at Kasturba Medical College, India. Educ Health 2004; 17(3): 280-91.

9. Al-Hazimi A, Zaini R, Al-Hyiani A, Hassan N, Gunaid A, Ponnamperuma G, Karunathilake I, Roff S, McAleer S, Davis $\mathrm{M}$ : Educational environment in traditional and innovative medical schools: a study in four undergraduate medical schools. Educ Health, 2004; 17(2): 192-203.

10. Al-Hazimi A, Al-hyiani A, Roff S: Perceptions of the educational environment of the medical school in King Abdul Aziz University, Saudi Arabia. Med Teacher, 2004; 26(6): 570-73.
11. Till H. Climate studies: can students' perceptions of the ideal educational environment be of use for institutional planning and resource utilization? Med Teacher 2005; 27(4): 332-37.

12. McAleer S, Roff S. (2001) A practical guide to using the Dundee Ready Education Environment Measure (DREEM). In Curriculum, Environment, Climate, Quality and Change in Medical Education: a Unifying Perspective. AMEE Education Guide No. 23. Dundee: Association for Medical Education in Europe Edited by: Genn JM, 2001: 29-33.

13. Siegel DM, Aten MJ, Roghmann KJ. Self-reported honesty among middle and high school students responding to a sexual behavior questionnaire. Journal of Adolescent Health 1998; 23: 20-8.

14. Polit DF, Hungler BP. Nursing research: Principles and methods, $5^{\text {th }}$ Ed. Philadelphia: Lippincott. 1995.

15. Guest AR, Roubidoux MA, Blane CE, Fitzgerald JT, Bowerman RA. Limitations of student evaluations of curriculum. Academic Radiology 1999; 6(4): 229-35. 